Agro-Science Journal of Tropical Agriculture, Food, Environment and Extension Volume 17 Number 3 (September 2018) pp. 7-11

ISSN 1119-7455

\title{
EFFECTS OF SOCIO-ECONOMIC FACTORS ON SMALL RUMINANT PRODUCTION IN OHAFIA AGRICULTURAL ZONE OF ABIA STATE, NIGERIA
}

\author{
*Offor E.I., Ekweanya N.M. and Oleka A.C. \\ Department of Agricultural Economics, Michael Okpara University of Agriculture, Umudike, Nigeria \\ *Corresponding author's email: offorevelyn53@gmail.com:
}

\begin{abstract}
The study investigated the socio-economic factors affecting small ruminant production in Ohafia Agricultural Zone of Abia state. Specifically the study examined the socioeconomic characteristic of the small ruminant farmers, management system of production, estimated the net return of the enterprises, determinants of small ruminant production and identify constraints militating against small ruminant animal production the study area. A multi stage sampling technique was used to sample for eighty (80) respondents from Bende and Ohafia local government areas, forty respondents from each respectively. Structured questionnaire was used to collect data for the study.Data collected were analyzed using descriptive such as frequency and percentages. More so gross margin and regression models were also used. Results of the study showed that the respondents had a mean age of thirty -nine (39) years. About $57.5 \%$ were males, $56.3 \%$ were married, $98.5 \%$ had one form of education or the other, a yearly income of $\$ 68,438$ was estimated. The gross margin estimate showed that the enterprise was profitable. The F-ratio was statistically significant at 5\%, socio-economic characteristics such as age, household size, income and rearing experience, were statistically significant at various level and were the major factor that influenced small ruminant production. Major constraints identified include; insufficient fund, disease incidence, and others. The study therefore recommends that younger people should be encouraged into small ruminant production because small ruminant animal production is laborious. The younger people are energetic to take up the task involved. The farmers should also form cooperative societies to increase their access to credit facilities.
\end{abstract}

Key words: socio-economic, characteristics, profit, small ruminants, production

\section{INTRDUCTION}

Livestock production is a very important segment of agriculture. It is referred to as one or more domesticated animals raised in agricultural settings to produce commodities such as food, fiber and labour. Apart from providing food, it serves as a source of employment and income generation to rural farm families. Livestock may be raised for subsistence or for profit (Enechi, et al., 2012). Livestock not only plays a significant role in the socio-cultural aspects of the people but also, helps to balance human nutrition (Adam et al., 2010). Furthermore, Baruwa (2013) also reported that they ensured the food security of a household, often being the only asset possessed by a poor family. In difficult situations, such as crop failure or family illness, sheep and goats can be sold and the proceeds used to purchase food and drugs for the family. The study also opined that dairy goats are good species for combating poverty and economic development in developing countries. Small ruminants are important domestic animals representing valuable resources in tropical livestock systems. Among all the livestock that make up the farm in Nigeria, small ruminants comprising sheep and goats constitute the farm animals largely reared by families in the country agriculture's system. Nigeria has a population of 34.5 million goats and 22.1 million sheep (Suleiman et al., 2015). Despite the importance of livestock in the economy and the large number of the different species, Nigeria has not been able to provide animal protein sufficient enough in quantity and quality to meet the per capital animal protein requirement of the citizens. This could be attributed to the production system and the factors that influenced the production of these small ruminant animals. Technical Centre for Agriculture and Rural Cooperation (CTA) (2009) reported that farm animals such as sheep, goats, pig, and rabbits are largely produced at subsistence level on small scale production. Especially in the eastern part of the country where livestock production is not taken 
as a means of livelihood like arable crop production when compare with the northern part where small ruminant animal production is carried out on commercial basis. Capital input which can be in the form of feed, stock of animals, housing and new breeding technologies could constitute a limiting factor in increasing the level of livestock production, especially in the intensive system of production. More so, majority of the small ruminant farmers are small scale farmers, limited in resource base and operation, due to low income. The paper therefore seeks to determine the extent socio-economic factors influencedsmall ruminantproduction in the study area. specifically the study (i) examined socio-economic characteristics of the respondents, (ii) determined the management practice used by farmers, (iii) ascertained the net return of small ruminant production, (iv) determined the effect of the socioeconomic characteristics on small ruminant production, and (v) identified constraints to small ruminants production in the study area.

\section{MATERIALS AND METHODS}

The study was conducted in Ohafia agricultural zone Abia state, Nigeria. The zone is made up of two Local Government Areas (LGAs) namely Bende and Ohafia. Bende LGA is located on latitude $5^{0} 34^{\prime}, 5.567 \mathrm{~N}$ and longitudes $7^{0} 38^{\prime}$, 7.633E. It has a land mass of $6320 \mathrm{~km}^{2}$ and an estimated population value of about 6320 National Bureau of Statistics (NBS, 2016). Ohafia LGA is situated on latitude $5^{0} 35^{\prime}, 5.617 \mathrm{~N}$ and longitude $7^{0}$ $8^{\prime,} 7.833 \mathrm{E}$ with a landmass of $715.07 \mathrm{~km}^{2}$ and an estimated population value of about 322,200 (NBS, 2016). The indigenes of the zone are Igbo speaking and their major occupation is farming. They are involved in crop and small ruminant animal production. Some of the crops produced include; rice, cassava, plantain yam and others. More so small ruminant such as sheep and goat are reared by the farmers. Primary data source was used to generate data for the study. Data were collected through the use ofstructured questionnaire. A multi stage sampling technique was employed for the study. In stage one (1) simple random technique was used to select four communities from each LGAs and a total of eight (8) communities were selected. In stage two, two (2) villages were randomly selected from each of the eight (8) communities to give a total of sixteen (16) villages. Finally, five (5) small ruminant farmers were purposively selected based on production activities from the sixteen (16) villages, making a total of eighty (80) respondents. Objectives i, ii and were realized using descriptive statistics; objectives iii and iv were analyzed using gross margin and multiple regression models respectively. The model as adopted from Onyebinama, (2004) is stated thus:

$$
G M=G I-T V C
$$

where

GM -Gross margin

GI - Gross income

TVC - Total variable cost,

The implicit form of the regression model is specified thus:

$$
\begin{gathered}
y=f\left(x_{1}, x_{2} x_{3}, x_{4}, x_{5}, x_{6}, x_{7}\right) \ldots(2) \\
Y=\text { output in naira }
\end{gathered}
$$

where

$X_{1}$ - Age (years)

$X_{2}$ - Household size (farmers)

$X_{3}$ - Income (naira)

$X_{4}$ - Gender (male -1 and female - 0)

$X_{5}$ - Rearing experience (years)

$X_{6}$ - Years of education

$X_{7}$ - Marital status

$X_{8}$ - Labour cost (naira)

\section{RESULTS AND DISCUSSIONS}

Socio Economic Characteristics of Small Ruminant Farmers in Ohafia Agricultural Zone of Abia State, Nigeria

Socio-economic characteristics of respondents are presented in Table 1. The socio-economic characteristics of the small ruminant farmers showed that farmers had a mean age of 39 years. This implies that the farmers were in their active age. About $57.5 \%$ of the respondents were men. This implies that more men were involved in small ruminant farming. This study is similar to findings of Faizal and Kwasi (2014) reported that more male farmers compared with female counterparts were principal producers of sheep and goat animals accounting for $(87.8 \%)$. Results also showed that $98 \%$ of the respondents had one form of education or the other implying that they can appreciate and embrace new technologies. The study also shows that the respondents had a relative small household size with a mean value of 6 persons. The study corroborates the findings of Fakoya and Oloruntoba (2009) who had a mean household size of six (6) persons. Majority of the respondents had a monthly income below $\$ 50,000$ implying they are low income earners hence cannot engage in large scale small ruminant production.

Management Practice Used by Farmers in Ohafia Agricultural Zone in Abia State Nigeria The management practice used by the small ruminant farmers in the study area is presented in Table 2. The dominant management system practiced by small ruminant farmers in the study area was permanent confinement.

The study shows that $44 \%$ of the farmers practiced permanent confinement. Furthermore, $41.25 \%$ of the farmers practiced partial confinement or tethering and $15 \%$ of the sampled respondents used the free rang management system 
where the animals are allowed to roam about and feed themselves. This is so because the management system was barned in the farming season in most communities due to the destructive nature of sheep and goat on people crops. However, the dominant system is labour intensive since labour is required to cut and carry folder for the animals as well as tethering the animals which required bringing and taking the animal to and fro from point of feeding each time of grazing. The findings is similar to the findings of Aphunu et al. (2011) who reported that cut and carry system was a dominant management system practiced among small ruminant producers in their study areas.

Cost and Returns Estimate of Small Ruminant Production in Bende and Ohafia LGAs of Abia State, Nigeria

Cost and returns estimate of small ruminant production in Bende and Ohafia LGAs of Abia State, is presented in Table 3. The data show that the estimated costs and return of sheep and goat enterprise in the study area were $\$ 114,000.00$ and $\$ 180, \quad 000.00$ yearly respectively. Cost of foundation stock accounted for $(39 \%)$ of the total cost while revenue from weaned kids had the highest share $(60 \%)$ of total revenue. The total revenue on the average was $\$ 180,000$ while the gross margin and net income were $\$ 77,500$ and $\$ 66,000$ respectively. The findings is in agreement with that of Kumar and Roy (2013) who obtained a gross margin of Rs 66,443 and net return of Rs 65,478 of Indian currency which implies that small ruminant enterprise was profitable in their study area. The profit margin percentage was $36.7 \%$ while the ratio of net returns to total expenses (return per Naira invested) was 0.58. This implies that every $\$ 1$ invested returned 58 kobo to the enterprise. The operating cost ratio of $56.9 \%$ indicates that $56.9 \%$ of gross revenue covered operating expenses, which accounted for about $90 \%$ of the total costs. A benefit cost ratio of 1.58 was obtained which is a further indicative of the profitability of sheep and goat enterprises in Bende and Ohafia LGAs of Abia State.

Socio-economic Factors that Influence Small Ruminant Production in Bende and Ohafia L.G.As, Abia State, Nigeria

The socio economic factors that influenced small ruminant production in the study area are presented in Table 4 . The result in Table 4 shows that six out of eight variables fitted in the regression model was significant at various levels. Double log functional form was chosen as the lead equation based on conformity with a priori expectation of signs and magnitude of coefficients. The F- statistics was significant at 5\% level of significance indicating goodness of fit. The coefficient of multiple determination (R2) value was estimated to be 0.78 this implies that $78 \%$ of total variation in the output of small ruminant production was accounted for by the independent variables that were fitted into the model. The regression result shows that variables like age $\left(X_{1}\right)$, household $\operatorname{size}\left(X_{2}\right)$, income $\left(X_{3}\right)$, $\operatorname{sex}\left(X_{4}\right)$, rearing experience $\left(X_{5}\right)$ and labour $\left(X_{8}\right)$ were significant. The coefficient of age was statistically significant at $1 \%$ level of significance but inversely related to small ruminant output. This implies that as the age of the farmers increases the output from small ruminant production decreases all things being equal. This means that age of farmers is of concern as older farmers are less likely to adopt new technologies; also the enterprises become more labourious for them hence there will be reduction in the output of small ruminant animals.

Table 1: Socio economic characteristic of small ruminant production in the study area

\begin{tabular}{|c|c|c|}
\hline+2 & Frequency & Percentage \\
\hline \multicolumn{3}{|l|}{ Age } \\
\hline$<20$ & 2 & 2.5 \\
\hline $21-30$ & 10 & 12.5 \\
\hline $31-40$ & 27 & 33.75 \\
\hline $41-50$ & 34 & 42.5 \\
\hline$>50$ & 7 & 8.70 \\
\hline Mean & 39.0 & \\
\hline \multicolumn{3}{|l|}{ Sex } \\
\hline Male & 46 & 57.5 \\
\hline Female & 34 & 42.5 \\
\hline \multicolumn{3}{|l|}{ Marital status } \\
\hline Single & 55 & 68.75 \\
\hline Widowed & 20 & 25.00 \\
\hline Divorced & 5 & 6.25 \\
\hline \multicolumn{3}{|l|}{ Household size } \\
\hline $1-5$ & 40 & 50.00 \\
\hline $6-10$ & 35 & 43.75 \\
\hline$>10$ & 5 & 6.25 \\
\hline Mean & 6 & \\
\hline \multicolumn{3}{|l|}{ Years of education } \\
\hline No formal education & 1 & 1.2 \\
\hline Primary & 10 & 12.5 \\
\hline Secondary & 40 & 50 \\
\hline Tertiary & 29 & 36.3 \\
\hline \multicolumn{3}{|l|}{ Level of income } \\
\hline$<50,000$ & 38 & 47.5 \\
\hline $50,000-100,000$ & 25 & 31.3 \\
\hline$>100,000$ & 17 & 21.2 \\
\hline Total & 80 & 100 \\
\hline
\end{tabular}

Table 2: Management systems practiced by farmers in the study area is presented in

\begin{tabular}{lll}
\hline Management system & Frequency & Percentage \\
Permanent confinement & 35 & 43.75 \\
$\begin{array}{c}\text { Partial confinement } \\
\text { (semi }- \text { intensive) }\end{array}$ & 33 & 41.25 \\
Free rage (extensive) & 12 & 15.0 \\
Total & 80 & 100 \\
\hline Source: Field survey 2015 & &
\end{tabular}


Table 3: Cost and returns estimate of small ruminant animals production in Bende and Ohafia LGA of Abia State

\begin{tabular}{|c|c|c|c|c|}
\hline Item & Average cost $(\mathbb{N})$ & No of stock owned & Amount (N) & Percentage \\
\hline \multicolumn{5}{|l|}{ A: Fixed Costs } \\
\hline Depreciation on house & 2000 & 2 & 4,000 & 100 \\
\hline \multicolumn{5}{|l|}{ B: Variable Costs } \\
\hline Foundation cost & 4000 & 10 weaned & $40,000.00$ & 39.0 \\
\hline Labour (family /and hired) & $1,500.00$ & 15 man-days & $22,500.00$ & 22.0 \\
\hline Medication & 500 & 10 & 5000.00 & 5.0 \\
\hline Veterinary services & 500 & 10 & $5,000.00$ & 5.0 \\
\hline Feeds & & & $30,000.00$ & 100 \\
\hline C: Total variable cost & & & $102,500.00$ & 100 \\
\hline D: Total Cost & & & $114,000.00$ & \\
\hline \multicolumn{5}{|l|}{ E: Returns/Revenue } \\
\hline Weaned kids and rams & 4,000 & 27 & 108,000 & 60.0 \\
\hline Culled doe and ewe & 8,000 & 9 & 72,000 & 40.0 \\
\hline F: Total Revenue & & & 180,000 & \\
\hline G: Net Farm Income (F-D) & & & 66,000 & \\
\hline $\mathrm{GM}=\mathrm{TR}-\mathrm{TVC}(\mathrm{F}-\mathrm{C})$ & & & 77,500 & \\
\hline Profit margin $\%(\mathrm{G} / \mathrm{F})$ & & & & 36.7 \\
\hline Operating cost Expenditure ratio $(\mathrm{C} / \mathrm{F})$ & & & & 56.9 \\
\hline Return/naira outlay (G/D) & & & & 57.9 \\
\hline Benefit /Cost Ratio (F/D) & & & & 1.58 \\
\hline
\end{tabular}

Source: Field survey 2015

This finding is contrary to that of Fakoya and Oloruntoba (2009) who reported that age of farmers had positive relationship with the output of small ruminant production. Similarly the coefficient of household size was significant but negatively related to output of small ruminants. This implies that increases in household size by one person, decreases the output of small ruminant by 0.03 unit. It could be said that individuals in these household act as a drain on household resources instead of source of labour supply. The coefficient of income and rearing experience were positively signed and statistically significant at $5 \%$ and $1 \%$ levels respectively. This implies that as the income from other sources of small ruminant farmers and their rearing experience increase the output of small ruminants also increase. Meaning that a unit increase in farmer income from other sources leads to 0.05 unit increase in the output of small ruminant animals, all things being equal. This agrees with the findings of Fakoya and Oloruntoba (2009) who reported that income and rearing experience had positive relationship with the output of small ruminant animal production. More so, the coefficient of sex was positively signed and significant at $5 \%$ level of probability. This shows that men dominated small ruminant production in the study area. The study agrees with the findings of Melissa et al. (2016) who opined that more men were involved /engaged in small ruminant production in the study area the coefficient of labour was highly significant at $1 \%$ level and had a positive relationship with small ruminant production. This implies that all things being equal, as labour input increases, output of small ruminant animal increases. This agrees with apriori expectation that, the more labour input put in, in an enterprise in term of care the higher the output from the enterprise especially at the rational stage of production.
Constraints that Militate against Small Ruminant Production in the Study Area

The constraints as identified by small ruminant farmers in the study area are presented in Table 5. From the study, the respondents identified inadequate fund availability to farmers as a major constraint. Also feeding and disease incidence were other serious constraints they identified. Other constraints in decreasing magnitude of importance included veterinary services, recommended strains of animals, lack of extension visit and pilfering. These agree with the findings of Aphunu et al. (2011) who reported that the respondents identified inadequate fund as their major constraints that militated against small ruminant production the study area.

Table 4: Regression estimate of the determinants of small ruminant production in the studyarea

\begin{tabular}{lllll}
\hline Parameter & Linear & $\begin{array}{l}\text { Semi- } \\
\log \end{array}$ & $\begin{array}{l}\text { Double } \\
\log +\end{array}$ & $\begin{array}{l}\text { Expo- } \\
\text { nential }\end{array}$ \\
\hline Constant & 1786.21 & 9.583 & 11.508 & 12.840 \\
Age & $(65.25)$ & $(0.338)$ & $(9.625)$ & $(9.023)$ \\
& 17.94 & 46.06 & -0.23 & 0.64 \\
Household & $(3.17)^{* * *}$ & $(1.40)$ & $(-1.31)^{* * *}$ & $(0.002)^{*}$ \\
& -26.08 & 40.08 & -0.03 & 2.01 \\
Income & $(2.29)^{* *}$ & $(1.54)^{*}$ & $(-1.40)^{*}$ & $(1.33)$ \\
& 29.9 & 37.91 & 0.05 & 12.12 \\
Gender & $(0.29)^{* *}$ & $(1.09)$ & $(2.64)^{* *}$ & $(11.21)$ \\
& 67.02 & 48.60 & 0.57 & 0.66 \\
Rearing & $(4.50)^{* *}$ & $(2.13)$ & $(-3.41)^{* *}$ & $(0.41)^{*}$ \\
experience & 99.30 & 13.34 & 0.03 & 0.45 \\
Educational & 34.24 & 0.20 & 0.024 & 4.64 \\
level & & & & \\
Marital & 0.26 & 1.06 & 1.23 & 13.14 \\
status & & & & \\
& $(0.15)^{*}$ & $(0.55)$ & $(1.02)$ & $(0.12)$ \\
Labour & -0.123 & 0.0009 & 0.44 & -504.11 \\
R & $(\mathbf{1 . 0 8 )}$ & $\mathbf{( 0 . 4 0 2 )}$ & $(\mathbf{2 . 6 8}) * * *$ & $(-\mathbf{0 . 2 4})$ \\
F-Stat & 0.76 & 0.67 & 0.78 & 0.71 \\
\hline Source: & $14.11 * *$ & $13.41 * *$ & $14.88 * *$ & $12.61 * *$ \\
\hline
\end{tabular}

Source: Field survey data, 2015: values in parentheses are $\mathrm{t}$ values, $* * *, * * *$ are $10 \%, 5 \%$ and $1 \%$ respectively 
Table 5: Constraints to small ruminant production in the study area

\begin{tabular}{lll}
\hline Constraints & Frequency & Percentage \\
\hline Insufficient fund & 47 & 58.8 \\
Diseases & 46 & 57.5 \\
Feeding & 46 & 57.5 \\
Veterinary services & 32 & 40.0 \\
Lack of recommended strain & 23 & 28.7 \\
of animals & & \\
Lack of extension visit & 22 & 27.5 \\
Pilfering & 15 & 18.8 \\
Total & 184 & 230 \\
\hline
\end{tabular}

Source: Field survey, 2015. Multiple responses were taken

hence total is more than sample size

\section{CONCLUSION}

Sheep and goats are important domestic animals representing valuable resources in tropical livestock production system. The valueof ownership of these animals is reflected in several advantages which include income, food security, employment, fertilizer, social values, wealth creation. Factors such as income, rearing experience and sex had positive relationship with the sheep and goat production while age and household size were negatively signed. The production system is labour intensive, which could hinder the quantity reared by farmers in a typical subsistent farming system. The production of small ruminant animals was profitable and more men were involved. Furthermore the respondents identified insufficient fund as the most important constraint that militated against the business.

\section{RECOMMENDATIONS}

Based on the findings of the study the following were recommended, that loan facilities be made available to provide adequate inputs. Farmers should be encouraged to form cooperative societies that could help them to mobilize saving and increase their access to finance. Young people should also be encouraged in to the business.

\section{REFERENCES}

Adam H., Atengdem P.B. and Al-hassan S. (2010) Innovations adoption levels of small ruminant farmers in Tolon-Kumbungu district of Ghana. Ghana Journal of Development Studies 7 (2), 39-66
Aphunu A., Okoedo and OKojie D.U. (2011). Small ruminant production constraints among farmers in Ika North-east Local Government Area of Delta State, Nigeria. Applied Science. Research, 3 (2), 370-376

Baruwa O.I. (2013).Empirical Analysis of Costs and Returns to Goat Production under Tropical Conditions. Journal of Livestock Science 4: 44-50.

CTA (2009). Technical Centre for Agriculture and Rural Cooperation, Study kids, Spore 140

Enechi G.N., Akinnagbe O.M. and Ajayi A.R. (2012). Assessments of livestock production system under climate change among farm-family in Nsukka Local Government Area of Enugu State. Published in Proceedings of the $17^{\text {th }}$ Annual Conference of Agricultural Extension Society of Nigeria (AESON) 2012, pp 5

Fakoyade E.O. and Oloruntoba A. (2009). Socioeconomic determinants of small ruminants production among farmers in Osun State, Nigeria. Journal of Humanities, Social Sciences and Creative Arts 4 (1), 90-100

Faizal A. and Kwasi O. (2014). Determinants of factors that influence small ruminant livestockproduction decisions in Northern Ghana: application of discrete regression model. Journal of Biology, Agriculture and Healthcare. (4). 27, 309-321

Kumar S. and Roy M.M. (2013). New Paradigms in livestock production from traditional to commercial farming and beyond (Eds) Prasad et al,Agrotech publishing academy Udaipur:57-80

Melissa A.Y., Norsida M. and Nolila M.N. (2016). Socio-economic factors in relation to small ruminant farming'potential in Malaysia: ranchers' perspective. International Journal of Agriculture, Forestry and Plantation, 2, 72-76

National Bureau of Statistics (NBS). (2016). Nigeria Population Estimate Abuja office Nigeria

Onyebinama U.A.U. (2004). Farm Business Management for Smallholder Farm Firms in Nigeria.Alphabet Nigeria Publishers Owerri, 45-49

Suleiman R., Olanrewaju T.O. and Abudu S. (2015). Socio-economic factors affecting goat production among rural households in Kaduna South Local Government Area of Kaduna State, Nigeria. Proceedings, $20^{\text {th }}$ Annual Conference of the Agricultural Extension Society of Nigeria held at the National Agricultural Extension and Research Liaison Services (NAERLS), Amadu Bello University, Zaria (15 ${ }^{\text {th }} 17^{\text {th }}$ May, 2015) $1595-1421$ 